\title{
Evaluation of Properties and Elements in the Surface of Acidic Soil in the Central Region of Thailand
}

\author{
Patarapong Kroeksakul*, Arin Ngamniyom, Kun Silprasit, Sakawjai \\ Tepamongkol, Punnada Teerapanaprinya and Kewaraporn Saichanda
}

Environment Major, Faculty of Environmental Culture and Ecotourism, Srinakharinwirot University, Thailand 10110

\begin{abstract}
The study aimed to evaluate and correlate acidic soil components to understand the phenomena of this type of soil. The soil samples were collected from 64 locations in 3 provinces of central Thailand and were tested for soil $\mathrm{pH}$, element content, soil organic matter (SOM), and soil organic carbon (SOC). The results show that soil acidity in central Thailand has an average $\mathrm{pH}$ of $4.71 \pm 0.87$. The soil acidity level ranges from very strongly acidic in Phatum Thani and Nakhon Nayok provinces to strongly acidic in Chachoengsao province. Soil bulk density is about $0.34 \mathrm{~g} / \mathrm{cm}^{3}$, and the correlation of soil $\mathrm{pH}$ to lead $(\mathrm{Pb})$, nickel $(\mathrm{Ni})$, nitrogen $(\mathrm{N})$, carbon-to-nitrogen ratio $(\mathrm{C} / \mathrm{N}$ ratio), and zinc $(\mathrm{Zn})$ is as follows: principle component $1(\mathrm{PC} 1)$ is carbon-to-nitrogen ratio $>\mathrm{pH}>$ zinc $(\mathrm{C} / \mathrm{N}$ ratio $>\mathrm{pH}>$ $\mathrm{Zn}$ ), and principle component 2 (PC2) is soil organic carbon $>$ bulk density $>$ soil organic matter $(\mathrm{SOC}>\mathrm{BD}>\mathrm{SOM})$. Soil $\mathrm{pH}$, SOM, and SOC are in similar groups. The soil

ARTICLE INFO

Article history:

Received: 24 February 2021

Accepted: 11 June 2021

Published: 20 August 2021

DOI: https://doi.org/10.47836/pjtas.44.3.03

E-mail addresses:

patarapong@g.swu.ac.th (Patarapong Kroeksakul)

arin@g.swu.ac.th (Arin Ngamniyom)

kun@g.swu.ac.th (Kun Silprasit)

sakawjai.tepamongkol@g.swu.ac.th (Sakawjai Tepamongkol)

punnada.teeratanaprinya@g.swu.ac.th (Punnada Teerapanaprinya)

kewaraporn.saichanda@g.swu.ac.th (Kewaraporn Saichanda)

*Corresponding author

abundance at the study site was compared with the ideal soil for plants, and heavy metal contamination in the acidic soil of the central region did not exceed the standard limit. The study found a correlation between SOM and SOM $(r=0.715 ; p<0.01)$, indicating soil quality and microbial activity.

Keywords: Acidic soil, central region, soil component, soil property
\end{abstract}


Patarapong Kroeksakul, Arin Ngamniyom, Kun Silprasit, Sakawjai Tepamongkol,

Punnada Teerapanaprinya and Kewaraporn Saichanda

\section{INTRODUCTION}

Soil is the main factor for success in agricultural production (Amenyan, 1988). Highly fertile soil produces a good agricultural yield (Parikh \& James, 2012), and soil with a pH below 5.5 will affect plant growth rate (Neina, 2019). Soil with a $\mathrm{pH}$ below 5.5 is considered acidic, so acidic soil covers about 3.95 million $\mathrm{km}^{2}$, or $27 \%$ of the world's land surface (von Uexküll \& Mutert, 1995). In Asia, acidic soil covers about 1.04 million $\mathrm{km}^{2}$ or $26 \%$ of the total area of acidic soil in the world (Van Ranst et al., 2004). In Thailand, sulfur is present on the soil surface (depth $>5 \mathrm{~cm}$ ) in about $8,904.5 \mathrm{~km}^{2}$, or approximately $0.000086 \%$ of the Asian acidic soil area. It is distributed throughout the country's central region, representing $5,097.4 \mathrm{~km}^{2}$, or $57.2 \%$ of the acidic soil in Thailand (Research and Development for Land Management Division, 2006).

The influence of soil acidity on various aspects of crop production, including growth, biomass allocation, nutrient uptake, mycorrhizal colonisation (Soti et al., 2015), and plant stress (Haling et al., 2011), is minimal. However, acidic soil may have a positive effect on the growth of some plants, such as tea and palm oil (Chien et al., 2019; Ho et al., 2019), and soil pH affects the mineralisation of organic material in the origin soil (parent soil) (Conyers et al., 1995).

Acidic soil covers the surface of the central region of Thailand in the irrigation zones and agricultural areas of Nonthaburi, Phathum Thani, Phanakhonsri Ayuthaya, Nakhon Nayok, and Chanchoengsao provinces. The water supply is essential to agricultural production in acidic soil zones because it affects the ion exchange between a liming material, such as calcium carbonate, and water, forming a hydroxyl group $\left(\mathrm{OH}^{-}\right)$ ion or the oxidation of organic sulfur (S) to sulfate ion ( $\mathrm{SO}_{4}^{2-}$ ) accompany by an equivalent quantity of hydrogen anion $\left(\mathrm{H}^{+}\right)$ (Freedman, 1995; Sparks, 2003). Without water, soil acidity will be a more significant factor in supporting agriculture in the area of bulk density (BD) when considering pores in the soil, soil organic matter (SOM), and soil organic carbon (SOC) along with organic fertility or soil biomass (Bautista et al., 2016) and multi-element. Therefore, it will also support agricultural production in acidic soil zones (Joris et al., 2013).

The objective of this study was to evaluate the relationship among acidic soil properties and analyse soil properties such as $\mathrm{pH}$, percentage of wet material in the soil, soil electrical conductivity (EC), soil moisture, BD, SOM, and SOC in Thailand's central region. In addition, this study also looks at element compounds in acidic soil and considers the correlation of these soil components. This information is essential in understanding the physiochemical phenomena of acidic soil in this zone and the influence of elements on plant nutrients, including heavy metals (Fontes \& Alleoni, 2006), so that techniques may be developed to improve future soil quality in the country.

\section{MATERIALS AND METHODS}

\section{Study Sites}

This study covers acid zones in 5 districts 
of 3 provinces: (1) In Nong Suea district Muang districts in Chachoengsao province, in Pathum Thani province, 21 soil samples 22 samples were collected from 7 zones. The were collected from 7 zones; (2) in study site focused on the agriculture area on Ongkharak and Banna districts in Nakhon Nayok province, 21 samples were collected from 7 zones; and (3) in Bangnampraw and the acidic soil map provided by the Land Development Department of Thailand, as presented in Figure 1 and Table 1.

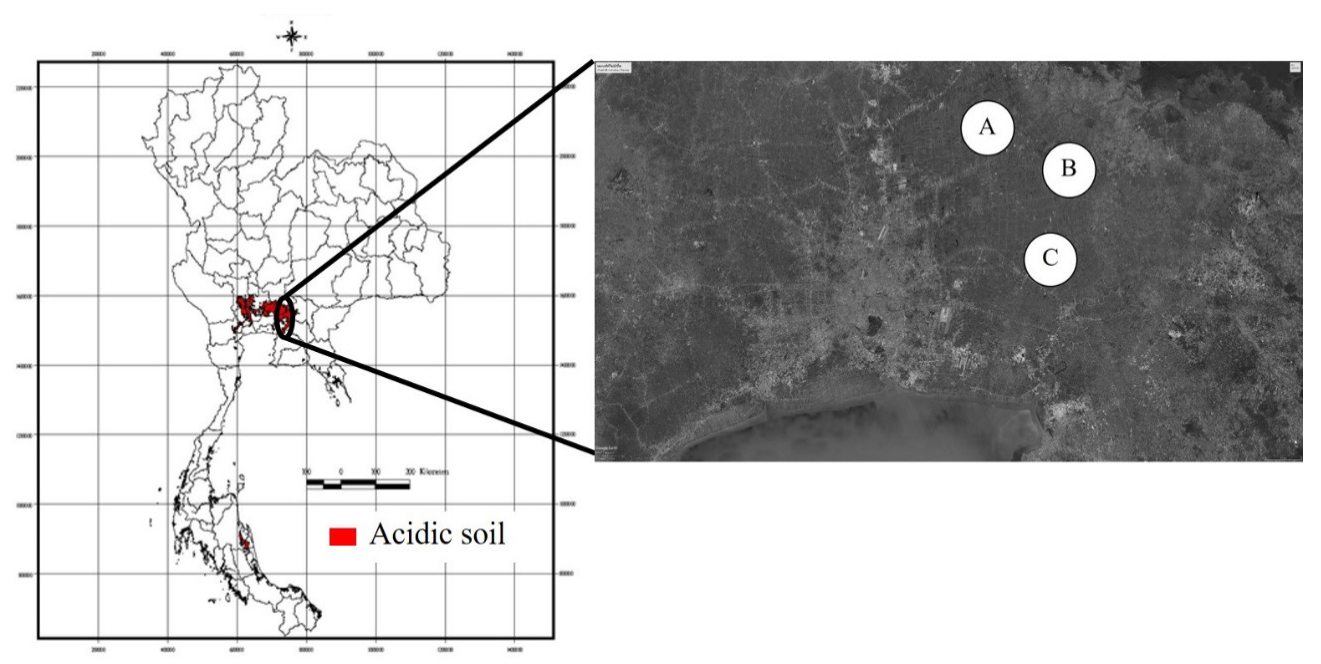

Figure 1. Study sites: (A) Nong Suea district in Pathum Thani province; (B) Ongkharak and Banna districts in Nakhon Nayok province; (C) Bangnampraw and Muang districts in Chachoengsao province

Table 1

Land use of study sites where soil samples were collected

\begin{tabular}{|c|c|c|c|c|c|c|c|c|}
\hline \multirow[t]{2}{*}{ Area } & \multicolumn{7}{|c|}{ Land use } & \multirow{2}{*}{$\begin{array}{c}\text { Total } \\
N\end{array}$} \\
\hline & 1 & 2 & 3 & 4 & 5 & 6 & 7 & \\
\hline A & $\begin{array}{c}\text { Banana } \\
\text { farm }\end{array}$ & $\begin{array}{l}\text { Lemon } \\
\text { garden }\end{array}$ & Orchard & $\begin{array}{l}\text { Papaya } \\
\text { garden }\end{array}$ & $\begin{array}{l}\text { Rubber } \\
\text { plantation }\end{array}$ & $\begin{array}{l}\text { Lemon } \\
\text { garden }\end{array}$ & $\begin{array}{c}\text { Cassava } \\
\text { field }\end{array}$ & 21 \\
\hline$N$ & (3) & (3) & (3) & (3) & (3) & (3) & (3) & \\
\hline B & Fallow & $\begin{array}{l}\text { Paddy } \\
\text { field }\end{array}$ & $\begin{array}{c}\text { Backyard } \\
\text { garden }\end{array}$ & $\begin{array}{c}\text { Banana } \\
\text { farm }\end{array}$ & Paddy field & Fallow & Abandoned & 21 \\
\hline$N$ & (3) & (3) & (3) & (3) & (3) & (3) & (3) & \\
\hline $\mathrm{C}$ & $\begin{array}{l}\text { Grass } \\
\text { field }\end{array}$ & $\begin{array}{c}\text { Lemon- } \\
\text { grass } \\
\text { field }\end{array}$ & $\begin{array}{l}\text { Galangal } \\
\text { field }\end{array}$ & $\begin{array}{l}\text { Paddy } \\
\text { field }\end{array}$ & $\begin{array}{l}\text { Integrated } \\
\text { farming }\end{array}$ & $\begin{array}{l}\text { Paddy } \\
\text { field }\end{array}$ & $\begin{array}{l}\text { Coconut } \\
\text { garden }\end{array}$ & 22 \\
\hline \multirow[t]{2}{*}{$N$} & (3) & (3) & (4) & (3) & (3) & (3) & (3) & \\
\hline & & & & & & \multicolumn{2}{|c|}{ Total samples } & 64 \\
\hline
\end{tabular}

Note. $N=$ sample collected from land classified as a farm zone 
Patarapong Kroeksakul, Arin Ngamniyom, Kun Silprasit, Sakawjai Tepamongkol,

Punnada Teerapanaprinya and Kewaraporn Saichanda

Soil Moisture, Soil Temperature, and Soil Electrical Conductivity

The moisture, temperature, and EC of soil collected from the surface $(0-5 \mathrm{~cm})$ and the data in the field survey on soil moisture-or percentage of wet soil (\% Wet) - temperature, and EC were collected using series HH2 Delta-T Devices. These are automatic instruments for collecting data.

\section{Soil pH Measurement and Validation}

The soil $\mathrm{pH}$ meter used for collecting data in the field survey (F.pH, the $\mathrm{pH}$ value that collected from the field) was a soil tester manufactured by Takemura Electric Works LTD (Japan). The pH value of the samples was then tested using a solution technique. The soil sample from the field (soil surface 0-5 cm) was dissolved in water at a 1:1 ratio of $5 \mathrm{~g}$ of soil diluted in $5 \mathrm{~mL}$ of deionized water and then stirred for 30 min. After waiting an additional $30 \mathrm{~min}$ to allow for precipitation, the liquid was separated from the sample for $\mathrm{pH}$ checking (L.pH, the $\mathrm{pH}$ value of the laboratory test) using a series HQ40d Portable Multi Meter by Hach (United States of America). However, regarding the variation between the laboratory and the field (McKean \& Brent, 1989; Neal \& Thomas, 1985), Shaver (1993) reported an average $\mathrm{pH}$ variation of +0.132 , as well as Lataysh and Gordon (2004) suggested that the $\mathrm{pH}$ value in the field will be greater than that in the laboratory by about $0.10 \mathrm{pH}$. In this report, the application of the soil $\mathrm{pH}$ value between fieldwork and laboratory analysis is derived from the following equation:

$$
\mathrm{pH}=\frac{(F \cdot p H+0.1)+(L . p H-0.1)}{2}
$$

The 0.1 value is applied according to Latysh and Gordon's (2004) observation ratio for balancing $\mathrm{pH}$ value.

\section{Soil Organic Carbon and Total Nitrogen}

In the study, total levels of carbon and nitrogen in the soil were measured using the LECO series CHN-628 CHN Analyzer (United States of America). After collection, the percentage of carbon in the soil was calculated as SOM using a formula from the Soil Lecture Team (2006):

$$
\% \mathrm{SOM}=100(\% \mathrm{C} / \mathrm{c})
$$

where $\% \mathrm{SOM}=$ Percentage of soil organic matter, \% $\mathrm{C}=$ Value from $\mathrm{CHN}$ analyzer processing, and $\mathrm{c}=\%$ Weight of SOC use 52 for topsoil calculated (Soil Lecture Team, 2006). \% SOM will be used to calculate the weight of SOM content in the soil according to the formula:

$$
\begin{aligned}
& \mathrm{SOM}(\mathrm{mg} / \mathrm{kg})=[\% \mathrm{SOM} \times(\mathrm{W} 1 / 100)] \\
& \times 10^{6}
\end{aligned}
$$

where $\mathrm{SOM}=$ Soil organic matter $(\mathrm{mg} / \mathrm{kg})$, $\% \mathrm{SOM}=$ Rate from the first equation, and $\mathrm{W}_{1}=$ Dry weight of the sample ( $\left.\mathrm{mg}\right)$ in the experiment using $2 \mathrm{mg} / \mathrm{sample}$.

However, SOC uses a soil sample from the topsoil at a depth of not more than 20 $\mathrm{cm}$, so Han et al. (2018) and Y. Liao et al. (2015) suggest the following calculation: 


$$
\operatorname{SOC}(\mathrm{mg} / \mathrm{kg})=\% \mathrm{SOM} \times 0.58 \times 100
$$

where $\mathrm{SOC}(\mathrm{mg} / \mathrm{kg})=$ Soil organic carbon concentration, \% SOM is from formula [1], and 0.58 is the van Bemmelen conversion factor of $58 \% \mathrm{C}$ in SOM.

\section{Elements in the Soil Content}

The soil was collected from 8 points (in a $\mathrm{Z}$ shape) in the field and mixed to create 1 sample (difference a soil to use find $\mathrm{BD}$ ). The soil was dried in a hot $105^{\circ} \mathrm{C}$ oven for 3 days and then ground using a mortar and pestle. A net $10 \mathrm{~mm}$ of sifted soil was selected and maintained at a temperature of $-4^{\circ} \mathrm{C}$. The soil extraction used in atomic absorption spectrometry (AAS) analysis was a $2 \mathrm{~g}$ soil sample with concentrated nitric acid $\left(\mathrm{HNO}_{3}\right)$ and concentrated perchloric acid $\left(\mathrm{HClO}_{4}\right)$ in a 1:1 ratio for $10 \mathrm{~mL}$ (United States Environmental Protection Agency, 1996). It was then digested at about $500^{\circ} \mathrm{C}$ in the SpeedDigester K-425 BUCHI (Switzerland) until dried. Each residue was rinsed with $1 \% \mathrm{HNO}_{3}$, followed by sieving through Whatman No. 1 paper. The supernatant was then transferred to a $50 \mathrm{~mL}$ volumetric flask, and $1 \% \mathrm{HNO}_{3}$ was added for continued AAS analysis (Thummahitsakul et al., 2018).

The mineral analysis set the standard of lead $(\mathrm{Pb})$, copper $(\mathrm{Cu})$, cadmium $(\mathrm{Cd})$, zinc $(\mathrm{Zn})$, selenium $(\mathrm{Se})$, iron $(\mathrm{Fe})$, mercury $(\mathrm{Hg})$, potassium $(\mathrm{K})$, and nickel $(\mathrm{Ni})$ prepared by a solution of an Agilent Technologies (United Sates of America) concentration of 1,000 $\mu \mathrm{g} / \mathrm{mL}$ stock of each heavy metal and $1 \%$ $\mathrm{HNO}_{3}$, with a linear standard calibration curve to measure mineral samples. The $\mathrm{Pb}, \mathrm{Cu}, \mathrm{Cd}, \mathrm{Zn}, \mathrm{Se}, \mathrm{Fe}, \mathrm{Hg}, \mathrm{K}$, and $\mathrm{Ni}$ analyzing by AAS, an Agilent series 240AA instrument (United Sates of America).

Whereas, phosphorus in the soil content was analysed using the Bray II method and measured by spectrophotometers in wavelength $882(\mathrm{~nm})$. Available phosphorus was in the form of potassium dihydrogen phosphate $\left(\mathrm{KH}_{2} \mathrm{PO}_{4}\right)$ in soil samples.

\section{Statistical Analysis}

Data were analysed using one-way analysis of variance (ANOVA) for variances. Differences in data were compared by post-hoc Tukey's honestly significant difference (HSD) test in $p<0.05$ between data components. Principal component analysis (PCA) evaluated correlation matrix components with factors of influence related to acidic soil in the central region. Correlation analysis considered the use of Pearson's correlation $(p<0.05)$. Finally, all analyses were conducted using the programs Statistical Package for the Social Sciences (SPSS) V.22 and SigmaPlot 12.0 (free trial).

\section{RESULTS AND DISCUSSION}

\section{Soil Physical Properties of the Study Sites}

In central Thailand, the soil $\mathrm{pH}$ ranged from 2.89-6.30, with an average of $4.71( \pm 0.87)$. The soil $\mathrm{pH}$ of Chachoengsao province has a significantly $(p<0.05)$ to that of Pathum Thani and Nakhon Nayok provinces (Table 2). The acidic soil of Phatum Thani and Nakhon Nayok is classified as extremely acidic (pH between 3.5-4.4), and the soil of Chachoengsao is classified as strongly acidic ( $\mathrm{pH}$ between 5.1-5.5), according 
to the Natural Resources Conservation Service (NRCS) (1994). The BD averaged $0.34 \pm 0.11 \mathrm{~g} / \mathrm{cm}^{3}$. Chachoengsao has a significantly $(p<0.05)$ lower BD $(0.28 \mathrm{~g} /$ $\left.\mathrm{cm}^{3}\right)$, while Phathum Thani $\left(0.37 \mathrm{~g} / \mathrm{cm}^{3}\right)$, but not significant to Nakhon Nayok provinces, have a BD of $0.35 \mathrm{~g} / \mathrm{cm}^{3}$. The result indicates that the areas are suitable for agriculture because of the characteristics of loam clay and because BD is related to soil texture and parent material. The $\%$ Wet in the soil averaged $36.9 \%( \pm 14.4)$. This high value can be attributed to the data being collected during the rainy season in Thailand. The EC averaged $205 \mu \mathrm{S}( \pm 133)$, soil temperature averaged $32.14^{\circ} \mathrm{C}( \pm 2.90)$, and the soil moisture level averaged $19.12 \%( \pm 5.21)$, as shown in Table 2 . The correlation of soil $\mathrm{pH}$ in relation to $\mathrm{EC}(r=0.274, p<0.05)$, $\mathrm{BD}$ in relation $\%$ Wet $(r=0.354, p<0.01)$, and $\%$ Wet and EC $(r=0.410, p<0.01)$ are presented in Table 3.

Table 2

Physical properties of acidic soil in central Thailand

\begin{tabular}{|c|c|c|c|c|c|c|}
\hline & $\mathrm{pH}$ & $\begin{array}{c}\text { Bulk } \\
\text { density } \\
\left(\mathrm{g} / \mathrm{cm}^{3}\right) \\
\end{array}$ & $\begin{array}{l}\text { Percentage } \\
\text { of wet soil } \\
\text { (\% Wet) }\end{array}$ & $\begin{array}{c}\text { Electrical } \\
\text { conductivity } \\
(\mu \mathrm{S})\end{array}$ & $\begin{array}{c}\text { Temperature } \\
\left({ }^{\circ} \mathrm{C}\right)\end{array}$ & $\begin{array}{c}\text { Moisture } \\
(\%)\end{array}$ \\
\hline Pathum Thani & $\begin{array}{c}4.41 \pm \\
0.59^{\mathrm{a}}\end{array}$ & $\begin{array}{c}0.37 \pm \\
0.06^{\mathrm{a}}\end{array}$ & $\begin{array}{l}41.8 \pm \\
17.35^{\mathrm{a}}\end{array}$ & $173 \pm 66.4$ & $33.9 \pm 2.80^{\mathrm{a}}$ & $\begin{array}{c}19.8 \pm \\
4.01^{\mathrm{b}}\end{array}$ \\
\hline $\begin{array}{l}\text { Nakhon } \\
\text { Nayok }\end{array}$ & $\begin{array}{c}4.18 \pm \\
0.82^{\mathrm{a}}\end{array}$ & $\begin{array}{l}0.35 \pm \\
0.08^{\mathrm{ab}}\end{array}$ & $\begin{array}{l}38.2 \pm \\
8.69^{\mathrm{ab}}\end{array}$ & $155 \pm 61.6$ & $29.8 \pm 2.45^{\mathrm{b}}$ & $\begin{array}{c}15.8 \pm \\
6.62^{\mathrm{a}}\end{array}$ \\
\hline Chachoengsao & $\begin{array}{c}5.50 \pm \\
0.54^{\mathrm{b}}\end{array}$ & $\begin{array}{l}0.28 \pm \\
0.15^{\mathrm{b}}\end{array}$ & $\begin{array}{l}31.1 \pm \\
15.50^{\mathrm{b}}\end{array}$ & $291 \pm 192$ & $32.6 \pm 1.77^{\mathrm{ab}}$ & $\begin{array}{l}21.5^{ \pm} \\
2.75^{\mathrm{b}}\end{array}$ \\
\hline Average & $\begin{array}{c}4.71 \pm \\
0.87\end{array}$ & $\begin{array}{c}0.34 \pm \\
0.11\end{array}$ & $\begin{array}{c}36.9 \pm \\
14.48\end{array}$ & $205 \pm 133$ & $32.1 \pm 2.90$ & $\begin{array}{c}19.1 \pm \\
5.21\end{array}$ \\
\hline
\end{tabular}

Note. ${ }^{\mathrm{a}, \mathrm{b}}$ The mean difference is significant at the $p$-value $<0.05$ level (HSD)

Table 3

Correlation of physical properties of acidic soil in central Thailand $(n=64)$

\begin{tabular}{lccccc}
\hline & $\mathrm{pH}$ & $\begin{array}{c}\text { Bulk density } \\
(\mathrm{BD})\end{array}$ & $\begin{array}{c}\text { Percentage of } \\
\text { wet soil } \\
(\% \mathrm{Wet})\end{array}$ & $\begin{array}{c}\text { Electrical } \\
\text { conductivity } \\
(\mu \mathrm{S})\end{array}$ & $\begin{array}{c}\text { Temperature } \\
\left({ }^{\circ} \mathrm{C}\right)\end{array}$ \\
\hline $\mathrm{BD}$ & -.030 & - & & & \\
$\%$ Wet & -.151 & $.394^{* *}$ & - & & \\
$\mathrm{EC}$ & $.274^{*}$ & $.354^{* *}$ & $.410^{* *}$ & - & \\
Temperature & -.048 & -.085 & -.070 & .110 & 1 \\
Moisture & .245 & .055 & .159 & .241 & .216 \\
\hline
\end{tabular}

Note. ${ }^{*}$ Correlation is significant at the 0.05 level $(2$-tailed); $* *$ Correlation is significant at the 0.01 level (2-tailed) 


\section{Relationship between SOC, SOM, and $\mathrm{C} / \mathrm{N}$ ratio in Acidic Soil in Central Thailand}

SOC is one indicator of soil quality and is related to microorganism activity. The SOC content of acidic soil in central Thailand averaged $404 \pm 303 \mathrm{mg} / \mathrm{kg}$, and the acidic soil level in Phatum Thani, Nakhon Nayok, and Chachoengsao was not significant $(p>0.05)$ (Table 4). The SOM averaged $9,036 \pm 4,048 \mathrm{mg} / \mathrm{kg}$, and the acidic soil level in Phatum Thani, Nakhon Nayok, and Chachoengsao was not significant ( $p>$ $0.05)$. The $\mathrm{C} / \mathrm{N}$ ratio averaged $3.69 \pm 2.13$, significant $(p<0.05)$ in Chachoengsao to Phatum Thani and Nakhon Nayok. However, when considering the correlation between $\mathrm{SOC}, \mathrm{SOM}$, and the $\mathrm{C} / \mathrm{N}$ ratio, it was found that SOM was related to SOC ( $r$ $=0.715 ; p<0.05)$, and SOM was related to the $\mathrm{C} / \mathrm{N}$ ratio $(r=0.283 ; p<0.05)$, as seen in Table 5. The $\mathrm{C} / \mathrm{N}$ ratio increased with the SOM value and decreased with the SOC rate, as presented in Figure 2.

Table 4

Average of SOC, SOM, and C/N ratio in acidic soil in central Thailand

\begin{tabular}{ccccc}
\hline Items & Phatum Thani & Nakhon Nayok & Chachoengsao & Average \\
\hline SOC $(\mathrm{mg} / \mathrm{kg})$ & $457 \pm 251^{\mathrm{a}}$ & $468 \pm 405^{\mathrm{a}}$ & $294 \pm 201^{\mathrm{a}}$ & $404 \pm 303$ \\
$\mathrm{SOM}(\mathrm{mg} / \mathrm{kg})$ & $9866 \pm 2627^{\mathrm{a}}$ & $9615 \pm 6045^{\mathrm{a}}$ & $7690 \pm 2207^{\mathrm{a}}$ & $9036 \pm 4048$ \\
C/N ratio & $3.29 \pm 1.22^{\mathrm{a}}$ & $1.21 \pm 0.89^{\mathrm{a}}$ & $5.05 \pm 2.04^{\mathrm{b}}$ & $3.69 \pm 2.13$ \\
\hline
\end{tabular}

Note. a,b,c The mean in row differences is significant at the $p$-value $<0.05$ level (HSD); SOC = Soil organic carbon; $\mathrm{SOM}=$ Soil organic matter; $\mathrm{C} / \mathrm{N}$ ratio $=$ Carbon-to-nitrogen ratio

Table 5

Correlation of SOC, SOM, and C/N ratio in acidic soil in central Thailand

\begin{tabular}{cccc}
\hline Item & SOC & SOM & C/N ratio \\
\hline SOC & & $0.715^{* *}$ & 0.118 \\
SOM & $0.715^{* *}$ & & $0.283^{*}$ \\
C/N ratio & 0.118 & $0.283^{*}$ & \\
\hline
\end{tabular}

Note. ${ }^{*}$ Correlation is significant at the 0.05 level (2-tailed); $* *$ Correlation is significant at the 0.01 level (2-tailed); $\mathrm{SOC}=$ Soil organic carbon; $\mathrm{SOM}=$ Soil organic matter; $\mathrm{C} / \mathrm{N}$ ratio $=$ Carbon-to-nitrogen ratio 


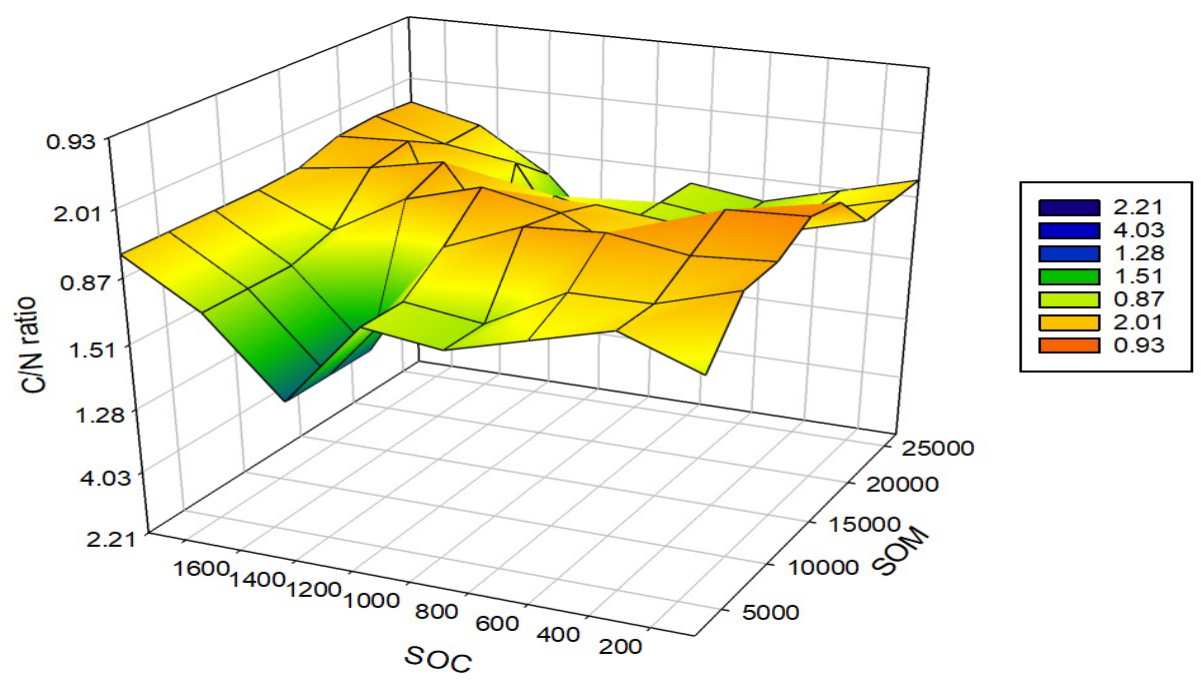

Figure 2. Evaluation rate of $\mathrm{C} / \mathrm{N}$ ratio between $\mathrm{SOC}$ and $\mathrm{SOM}$ in acidic soil in central Thailand

\section{Elements of Acidic Soil Content}

The study of the mineral content of acidic soil in the central region found Fe present in the highest quantity. At the same time, $\mathrm{Ni}$ made up the smallest quantity, as presented in Table 6. Soil elements can be classified into three groups: essential macroelements, including $\mathrm{N}, \mathrm{P}$, and $\mathrm{K}$; essential microelements, such as $\mathrm{Fe}, \mathrm{Cu}$, $\mathrm{Zn}$, and $\mathrm{Ni}$; and heavy metals, like $\mathrm{Pb}$, $\mathrm{Cd}, \mathrm{Hg}$, and Se. The number of essential macroelements showed that $\mathrm{N}>\mathrm{P}>\mathrm{K}$, and the quantity of $\mathrm{N}$ content in Nakhon Nayok $>$ Phatum Thani $>$ Chachoengsao was significant $(p<0.05)$. P levels in the soil content in Phatum Thani and Chachoengsao were significantly higher $(p<0.05)$ than those in Nakhon Nayok, and K levels found in the soil content in Phatum Thani and Chachoengsao were significant $(p<0.05)$, as presented in Table 7. The proportion of $\mathrm{N}, \mathrm{P}$, and $\mathrm{K}$ in acidic soil is a 13:2:1 ratio.

The number of essential plant microminerals in acidic soil content was $\mathrm{Fe}>\mathrm{Cu}>\mathrm{Zn}>\mathrm{Ni}$. The results showed that the quantity of $\mathrm{Fe}$ and $\mathrm{Zn}$ in Phatum Thani and Chachoengsao was significant $(p<0.05)$ compared to Nakhon Nayok province. Phatum Thani's Cu quantity was higher $(p<0.05)$ than that of Nakhon Nayok and Chachoengsao provinces, and the $\mathrm{Ni}$ quantity of the three provinces differed ( $p$ $<0.05$ ), as shown in Table 7 .

The quantity of the heavy metal $\mathrm{Pb}$ in Nakhon Nayok was higher than in Phatum Thani and Chachoengsao $(p<0.05)$, and the quantity of $\mathrm{Hg}$ found in Phatum Thani and Nakhon Nayok was not significant ( $p<$ $0.05)$ compared to Chachoengsao. However, differences in $\mathrm{Cd}$ and $\mathrm{Se}$ levels between the three provinces were small. 
Table 6

Average total quantity of elements in acidic soil in the central region

\begin{tabular}{cccc}
\hline Elements $(\mathrm{mg} / \mathrm{kg})$ & Average & $\mathrm{SD}$ & $\%$ \\
\hline $\mathrm{Pb}$ & 130 & 103 & 0.42 \\
$\mathrm{Cd}$ & 2.25 & 1.78 & 0.02 \\
$\mathrm{Hg}$ & 5.43 & 2.16 & 0.03 \\
$\mathrm{Se}$ & 1.83 & 0.70 & 0.01 \\
$\mathrm{Fe}$ & 29765 & 8921 & 96.2 \\
$\mathrm{Cu}$ & 40.56 & 40.2 & 0.13 \\
$\mathrm{Zn}$ & 13.35 & 12.2 & 0.04 \\
$\mathrm{Ni}$ & 0.19 & 0.04 & 0.00 \\
$\mathrm{~N}$ & 782 & 377 & 2.53 \\
$\mathrm{P*}$ & 131 & 122 & 0.42 \\
$\mathrm{~K}$ & 61 & 29 & 0.2 \\
\hline
\end{tabular}

*P was determined using the Bray II method. The phosphorus considers $\mathrm{P}$ available from potassium dihydrogen phosphate $\left(\mathrm{KH}_{2} \mathrm{PO}_{4}\right) ; \mathrm{Pb}=\mathrm{Lead} ; \mathrm{Cd}=$ Cadmium; $\mathrm{Hg}=$ Mercury; $\mathrm{Se}=$ Selenium; $\mathrm{Fe}=$ Iron; $\mathrm{Cu}=$ Copper; $\mathrm{Zn}=$ Zinc; $\mathrm{Ni}=$ Nickel; $\mathrm{N}=$ Nitrogen; $\mathrm{P}=$ Phosphorus; $\mathrm{K}=$ Potassium

Table 7

The quantity of elements for plants in acidic soil content classified by group and province

\begin{tabular}{|c|c|c|c|}
\hline & Phatum Thani & Nakhon Nayok & Chachoengsao \\
\hline \multicolumn{4}{|c|}{$\begin{array}{l}\text { Essential macro-elements } \\
(\mathrm{mg} / \mathrm{kg})\end{array}$} \\
\hline $\mathrm{N}$ & $842 \pm 237^{b}$ & $1,097 \pm 359^{\mathrm{a}}$ & $425 \pm 124^{c}$ \\
\hline$P$ & $193 \pm 151^{\mathrm{a}}$ & $80.7 \pm 81.4^{\mathrm{b}}$ & $121 \pm 102^{\mathrm{a}}$ \\
\hline K & $74.2 \pm 25.6^{\mathrm{a}}$ & $63 \pm 34.5^{\mathrm{ab}}$ & $47.5 \pm 19.9^{b}$ \\
\hline \multicolumn{4}{|c|}{$\begin{array}{l}\text { Essential micro-minerals } \\
(\mathrm{mg} / \mathrm{kg})\end{array}$} \\
\hline $\mathrm{Fe}$ & $34,479 \pm 7,755^{a}$ & $23,997 \pm 9,368^{b}$ & $30,772 \pm 6,430^{\mathrm{a}}$ \\
\hline $\mathrm{Cu}$ & $68.4 \pm 58.6^{\mathrm{a}}$ & $23.3 \pm 11.1^{\mathrm{b}}$ & $30.2 \pm 16.8^{b}$ \\
\hline $\mathrm{Zn}$ & $15.2 \pm 12.8^{\mathrm{a}}$ & $6.49 \pm 7.29^{b}$ & $18.1 \pm 12.9^{\mathrm{a}}$ \\
\hline $\mathrm{Ni}$ & $0.18 \pm 0.05^{b}$ & $0.23 \pm 0.03^{c}$ & $0.16 \pm 0.04^{\mathrm{a}}$ \\
\hline
\end{tabular}




\begin{tabular}{lccc}
\hline & Phatum Thani & Nakhon Nayok & Chachoengsao \\
\hline Heavy metals $(\mathrm{mg} / \mathrm{kg})$ & & & \\
$\mathrm{Pb}$ & $82.5 \pm 31.3^{\mathrm{a}}$ & $226 \pm 135^{\mathrm{b}}$ & $85.6 \pm 11.8^{\mathrm{a}}$ \\
$\mathrm{Cd}$ & $2.75 \pm 0.89^{\mathrm{a}}$ & $2.11 \pm 0.99^{\mathrm{a}}$ & $1.89 \pm 2.73^{\mathrm{a}}$ \\
$\mathrm{Hg}$ & $5.13 \pm 2.61^{\mathrm{a}}$ & $6.33 \pm 1.77^{\mathrm{a}}$ & $4.86 \pm 1.81^{\mathrm{a}}$ \\
$\mathrm{Se}$ & $1.90 \pm 0.12^{\mathrm{a}}$ & $4.86 \pm 11.9^{\mathrm{b}}$ & $1.20 \pm 0.37^{\mathrm{c}}$ \\
\hline
\end{tabular}

Note. ${ }^{\text {ab,c, }}$ The mean in row differences is significant at the $p$-value $<0.05$ level (HSD); $\mathrm{N}=$ Nitrogen; $\mathrm{P}=$ Phosphorus; $\mathrm{K}=$ Potassium; $\mathrm{Fe}=$ Iron; $\mathrm{Cu}=$ Copper; $\mathrm{Zn}=\mathrm{Zinc} ; \mathrm{Ni}=$ Nickel; $\mathrm{Pb}=$ Lead; $\mathrm{Cd}=$ Cadmium; $\mathrm{Hg}=$ Mercury; $\mathrm{Se}=$ Selenium

\section{Relationship of Some Elements to Acidic Soil}

The results of the correlation of acidic soil with elements $\mathrm{Pb}, \mathrm{Cu}, \mathrm{Cd}, \mathrm{Zn}$, Se, $\mathrm{Fe}, \mathrm{Hg}, \mathrm{Ni}, \mathrm{K}, \mathrm{P}$, and $\mathrm{N}$ are as follows. In the soil, $\mathrm{pH}$ was tested using Pearson's correlation coefficient. Levels of $\mathrm{N}(r$ $=-0.606 ; p<0.01)$, Ni $(r=-0.339 ; p$ $<0.01), \mathrm{Pb}(r=-0.503 ; p<0.01)$, and $\mathrm{Zn}(r=0.292 ; p<0.05)$ are presented in Table 8 . The correlation between $\mathrm{N}$ and soil $\mathrm{pH}$ is negative because, in soil, $\mathrm{N}$ forms ammonium $\left(\mathrm{NH}_{4}^{+}\right)$and undergoes nitrification by microorganisms present in the hydrogen $\left(\mathrm{H}^{+}\right)$in the environment, which is related to an increase in soil acidity. The correlation of $\mathrm{N}$ to soil $\mathrm{pH}$ is in accordance with the relationship between soil $\mathrm{pH}$ and the $\mathrm{C} / \mathrm{N}$ ratio $(r=0.690 ; p<0.01)$, so soil $\mathrm{pH}$ is possibly affected by heterotrophic nitrification because a neutral soil $\mathrm{pH}(\mathrm{pH}$ 6-7) is suitable for microorganism activity (Zhang et al., 2019).

Table 8

Correlation of soil physical properties, mineral soil content, SOC, SOM, and C/N ratio of acidic soil in central Thailand

\begin{tabular}{lcccccccc}
\hline & $\mathrm{pH}$ & $\mathrm{BD}$ & $\mathrm{Pb}$ & $\mathrm{Cu}$ & $\mathrm{Cd}$ & $\mathrm{Zn}$ & $\mathrm{Se}$ & $\mathrm{Fe}$ \\
\hline $\mathrm{BD}$ & $\mathrm{ns}$ & & & & & & & \\
$\mathrm{Pb}$ & $-.503^{* *}$ & $\mathrm{~ns}$ & & & & & & \\
$\mathrm{Cu}$ & $\mathrm{ns}$ & $\mathrm{ns}$ & $\mathrm{ns}$ & & & & & \\
$\mathrm{Cd}$ & $\mathrm{ns}$ & $\mathrm{ns}$ & $\mathrm{ns}$ & $\mathrm{ns}$ & & & & \\
$\mathrm{Zn}$ & $.292^{*}$ & $\mathrm{~ns}$ & $-.255^{*}$ & $.494^{* *}$ & $\mathrm{~ns}$ & & & \\
$\mathrm{Se}$ & $\mathrm{ns}$ & $.247^{*}$ & $\mathrm{~ns}$ & $\mathrm{~ns}$ & $\mathrm{~ns}$ & $\mathrm{~ns}$ & & \\
$\mathrm{Fe}$ & $\mathrm{ns}$ & $\mathrm{ns}$ & $-.450^{* *}$ & $\mathrm{~ns}$ & $\mathrm{~ns}$ & $\mathrm{~ns}$ & $\mathrm{~ns}$ & \\
\hline
\end{tabular}




\begin{tabular}{|c|c|c|c|c|c|c|c|c|}
\hline & $\mathrm{pH}$ & $\mathrm{BD}$ & $\mathrm{Pb}$ & $\mathrm{Cu}$ & $\mathrm{Cd}$ & $\mathrm{Zn}$ & $\mathrm{Se}$ & $\mathrm{Fe}$ \\
\hline $\mathrm{Hg}$ & $\mathrm{ns}$ & $\mathrm{ns}$ & ns & $\mathrm{ns}$ & $\mathrm{ns}$ & $\mathrm{ns}$ & $\mathrm{ns}$ & $\mathrm{ns}$ \\
\hline K & ns & ns & ns & $\mathrm{ns}$ & $\mathrm{ns}$ & ns & ns & $\mathrm{ns}$ \\
\hline $\mathrm{Ni}$ & $-.339 * *$ & ns & $.508 * *$ & $\mathrm{~ns}$ & ns & $-.330 * *$ & ns & $-.423 * *$ \\
\hline $\mathrm{P}$ & ns & ns & ns & ns & ns & $\mathrm{ns}$ & ns & ns \\
\hline $\mathrm{N}$ & $-.606 * *$ & ns & $.573 * *$ & ns & ns & $-.388 * *$ & ns & $-.265^{*}$ \\
\hline SOM & ns & $.273 *$ & $\mathrm{~ns}$ & ns & ns & ns & ns & $\mathrm{ns}$ \\
\hline SOC & ns & $.597 * *$ & ns & ns & ns & ns & $.254^{*}$ & ns \\
\hline $\begin{array}{l}\mathrm{C} / \mathrm{N} \\
\text { ratio }\end{array}$ & $.690 * *$ & ns & $-.508 * *$ & $\mathrm{~ns}$ & $\mathrm{~ns}$ & $.515^{* *}$ & ns & $\mathrm{ns}$ \\
\hline & $\mathrm{Hg}$ & $\mathrm{K}$ & $\mathrm{Ni}$ & $\mathrm{P}$ & $\mathrm{N}$ & SOM & SOC & $\begin{array}{l}\mathrm{C} / \mathrm{N} \\
\text { ratio }\end{array}$ \\
\hline $\mathrm{K}$ & ns & & & & & & & \\
\hline $\mathrm{Ni}$ & ns & ns & & & & & & \\
\hline $\mathrm{P}$ & $-.385 * *$ & ns & $\mathrm{ns}$ & & & & & \\
\hline $\mathrm{N}$ & & $\mathrm{ns}$ & $.547 * *$ & ns & & & & \\
\hline SOM & ns & $\mathrm{ns}$ & ns & ns & $\mathrm{ns}$ & & & \\
\hline SOC & ns & ns & ns & ns & $\mathrm{ns}$ & $.715^{* *}$ & & \\
\hline $\begin{array}{l}\mathrm{C} / \mathrm{N} \\
\text { ratio }\end{array}$ & $-.251 *$ & ns & $-.424 * *$ & ns & $-.741 * *$ & $.283 *$ & ns & \\
\hline
\end{tabular}

Note. ${ }^{*}$ Correlation is significant at the 0.05 level (2-tailed); ${ }^{*}$ Correlation is significant at the 0.01 level (2-tailed); $\mathrm{BD}=$ Bulk density; $\mathrm{Pb}=$ Lead; $\mathrm{Cu}=$ Copper; $\mathrm{Cd}=$ Cadmium; $\mathrm{Zn}=\mathrm{Zinc} ; \mathrm{Se}=$ Selenium; Fe = Iron; $\mathrm{Hg}=$ Mercury; $\mathrm{K}=$ Potassium; Ni = Nickel; $\mathrm{P}=$ Phosphorus; $\mathrm{N}=$ Nitrogen; $\mathrm{SOM}=$ Soil organic matter; SOC

$=$ Soil organic carbon; $\mathrm{C} / \mathrm{N}$ ratio $=$ Carbon-to-nitrogen ratio; $\mathrm{ns}=$ Not significant

\section{Factors of Acidic Soil Components}

Factor analysis of the parameters of the 16 components of acidic soil properties was done by PCA. Prior to this, acidic soil components were tested using KaiserMeyer-Olkin (KMO) and Bartlett's test. The KMO Measure of Sampling Adequacy was 0.618 (Table 9), and there was a significant difference in the eigenvalues $(p<0.001)$. The components found in six PCs had an eigenvalue over 1 and explained 71.628\% of the total variance in the data set (Table 10). The components had a percentage of the variance of $>10 \%$, as shown in $\mathrm{PC} 1$ and PC2. PC1 had $24.047 \%$ of the variance (Table 10, Figure $3 \mathrm{a}$ ). The $\mathrm{C} / \mathrm{N}$ ratio was the most significant contributor, and factor loading was 0.853 , which was selected first. Second were soil $\mathrm{pH}(0.712)$ and $\mathrm{Zn}$ (0.598), so the correlation between $\mathrm{C} / \mathrm{N}$ 
ratio and soil $\mathrm{pH}$ was $r=0.692$, and the correlation between $\mathrm{C} / \mathrm{N}$ ratio and $\mathrm{Zn}$ was $r$ $=0.515$ (Table 8 ). PC2 explained $14.887 \%$ of the variances (Table 10). SOC was the most significant contributor, and factor loading was 0.873 , which was selected first. Second were BD (0.748) and SOM (0.717), so the correlation between SOC and BD was $r=0.597$, and the correlation between SOC and SOM was $r=0.715$ (Table 8). The relationship of an eigenvalue to components in principle analysis and component loading of PCs is presented in Figure 3(b). Figure
4 shows the cluster analysis for classified groups as a dendrogram. This dendrogram construction presents two major, distinct clusters with four groups from SOC and SOM clustered together in one group and $\mathrm{Pb}, \mathrm{Se}, \mathrm{pH}$, and $\mathrm{C} / \mathrm{N}$ ratio in another. The third group comprises Fe, soil moisture, $\mathrm{Cu}, \mathrm{Zn}$, percentage of wet material in the soil, and EC. The final group contains $\mathrm{P}$, $\mathrm{Hg}$, and soil temperature. This final group is dissimilar to groups $\mathrm{A}, \mathrm{B}$, and $\mathrm{C} . \mathrm{K}$ and $\mathrm{Cd}$ could not be grouped with the others (Figure 4).

Table 9

Results of KMO and Bartlett's test of acidic soil components in central Thailand

\begin{tabular}{ll}
\hline Kaiser-Meyer-Olkin Measure of Sampling Adequacy & .618 \\
Bartlett's Test of Sphericity Approximate Chi-Square & 367.983 \\
df & 120 \\
\hline Sig. & .000 \\
\hline
\end{tabular}

Note $. \mathrm{df}=$ Degree of freedom; Sig. $=$ Significant

Table 10

Results of PCA of the statically significance of acidic soil in central Thailand

\begin{tabular}{lcccccc}
\hline \multirow{2}{*}{ PCs } & \multicolumn{7}{c}{ Component } \\
\cline { 2 - 7 } & PC1 & PC2 & PC3 & PC4 & PC5 & PC6 \\
\hline \% of variance & 24.04 & 14.8 & 10.03 & 8.83 & 7.50 & 6.32 \\
Cumulative \% & 24.04 & 38.9 & 48.9 & 57.8 & 65.3 & 71.6 \\
Eigenvalue & 3.84 & 2.38 & 1.60 & 1.41 & 1.20 & 1.01 \\
pH & .71 & -.08 & -.41 & -.08 & -.02 & -.06 \\
SOM & .17 & .71 & -.36 & -.10 & -.07 & .31 \\
C/N ratio & .85 & -.02 & -.24 & -.17 & .08 & .09 \\
SOC & .16 & .87 & -.16 & .04 & .14 & .07 \\
\hline
\end{tabular}


Table 10 (Continued)

\begin{tabular}{lcccccc}
\hline \multirow{2}{*}{ PCs } & \multicolumn{7}{c}{ Component } \\
\cline { 2 - 7 } & PC1 & PC2 & PC3 & PC4 & PC5 & PC6 \\
\hline $\mathrm{BD}$ & -.01 & .74 & .04 & .23 & .11 & -.27 \\
$\mathrm{~Pb}$ & -.76 & -.09 & -.00 & -.26 & .21 & .06 \\
$\mathrm{Cu}$ & .36 & .18 & .51 & -.03 & .47 & .19 \\
$\mathrm{Cd}$ & -.17 & .10 & -.02 & .56 & -.04 & .49 \\
$\mathrm{Zn}$ & .59 & .01 & .28 & -.31 & .48 & .09 \\
$\mathrm{Se}$ & -.08 & .42 & -.18 & -.12 & -.22 & -.49 \\
$\mathrm{Fe}$ & .39 & -.01 & .21 & .70 & -.20 & .01 \\
$\mathrm{Hg}$ & -.31 & -.02 & -.22 & .45 & .64 & -.29 \\
$\mathrm{Ni}$ & -.67 & .31 & -.16 & -.26 & .03 & .19 \\
$\mathrm{~K}$ & -.06 & .23 & .55 & -.01 & -.01 & -.33 \\
$\mathrm{P}$ & .21 & .35 & .60 & -.16 & -.36 & .07 \\
$\mathrm{~N}$ & -.82 & .14 & .18 & -.03 & .00 & .18 \\
\hline
\end{tabular}

Note. $\mathrm{PC}=$ Principal analysis; underlined factor loading is weighted higher when within $10 \%$ of the variation of the absolute value of the highest factor loading in each $\mathrm{PC}$; SOM $=$ Soil organic matter; $\mathrm{C} / \mathrm{N}$ ratio = Carbon-to-nitrogen ratio; $\mathrm{SOC}=$ Soil organic carbon; $\mathrm{BD}=$ Bulk density; $\mathrm{Pb}=$ Lead; $\mathrm{Cu}=$ Copper; $\mathrm{Cd}=$ Cadmium; Zn = Zinc; Se = Selenium; Fe = Iron; Hg = Mercury; $\mathrm{Ni}=$ Nickel; $\mathrm{K}=$ Potassium; $\mathrm{P}=$ Phosphorus; $\mathrm{N}=$ Nitrogen

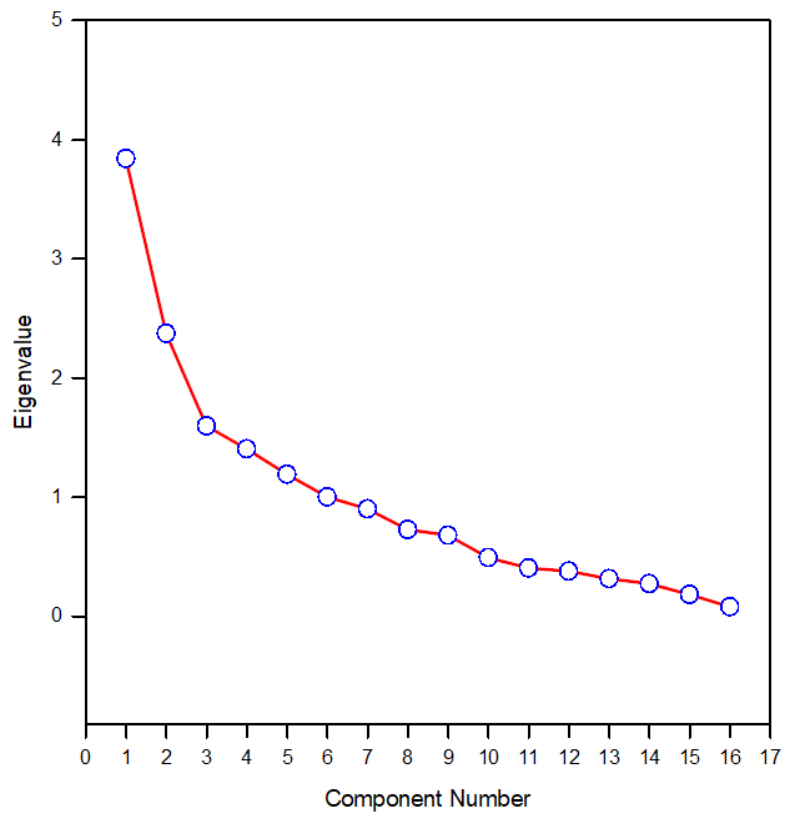

(a) 


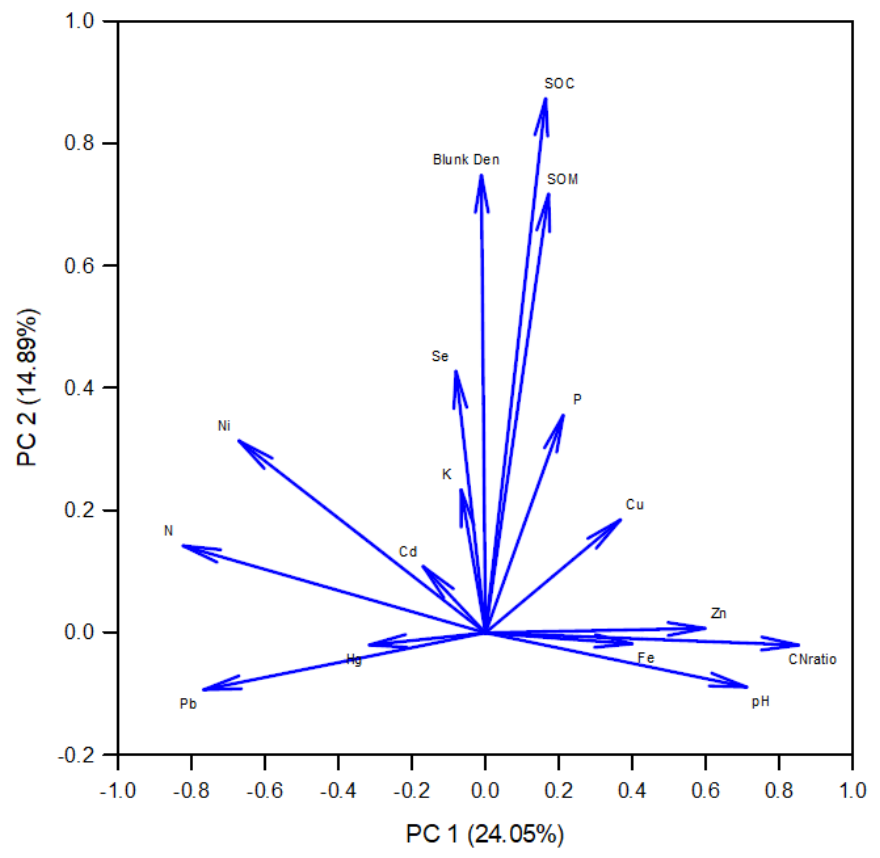

(b)

Figure 3. Results of PCA for acidic soil components in central Thailand: (a) the eigenvalue of components in principal analysis; (b) the component loading of PCs, so PC1 is carbon-to-nitrogen ratio $>\mathrm{pH}>\mathrm{zinc}(\mathrm{C} / \mathrm{N}$ ratio $>\mathrm{pH}>\mathrm{Zn}$ ), and $\mathrm{PC} 2$ is soil organic carbon $>$ bulk density $>$ soil organic matter $(\mathrm{SOC}>\mathrm{BD}>\mathrm{SOM})$

Physical and Land Use of Acidic Soil in Central Thailand

The soil $\mathrm{pH}$ of the study sites in Phatum Thani and Nakhon Nayok is in the extremely acidic group; some Phatum Thani parts have ultra-acidic soil with a $\mathrm{pH}$ below 3.5 (Attanandana, 1993; Intorpetch et al., 2014). Nakhon Nayok has a soil pH below 4 (Seeboonruang \& Ichikawa, 2007), and Chachoengsao belongs to the strongly acidic group because soil $\mathrm{pH}$ in the province is between 4.3 and 6 (Prawach et al., 2017). However, soil pH below 5.5 will affect plant growth (Sumner et al., 1991). Therefore, low $\mathrm{pH}$ levels may be an obstacle to agricultural production. Farmers apply manure and water to the soil to prepare the land for planting. Because the study site sits almost entirely inside the irrigation zone, the water supply is directly related to the percentage of wet material in the soil and the soil EC (Lesturgez et al., 2006; Parkpian et al., 1991), supporting the plant growth mechanism.

\section{Influence of soil pH on Some Indicators of Acidic Soil}

Soil pH is essential to agricultural production because of its connection to the biogeochemistry of plant and 
Evaluation of Properties and Elements in Acidic Soil of Thailand

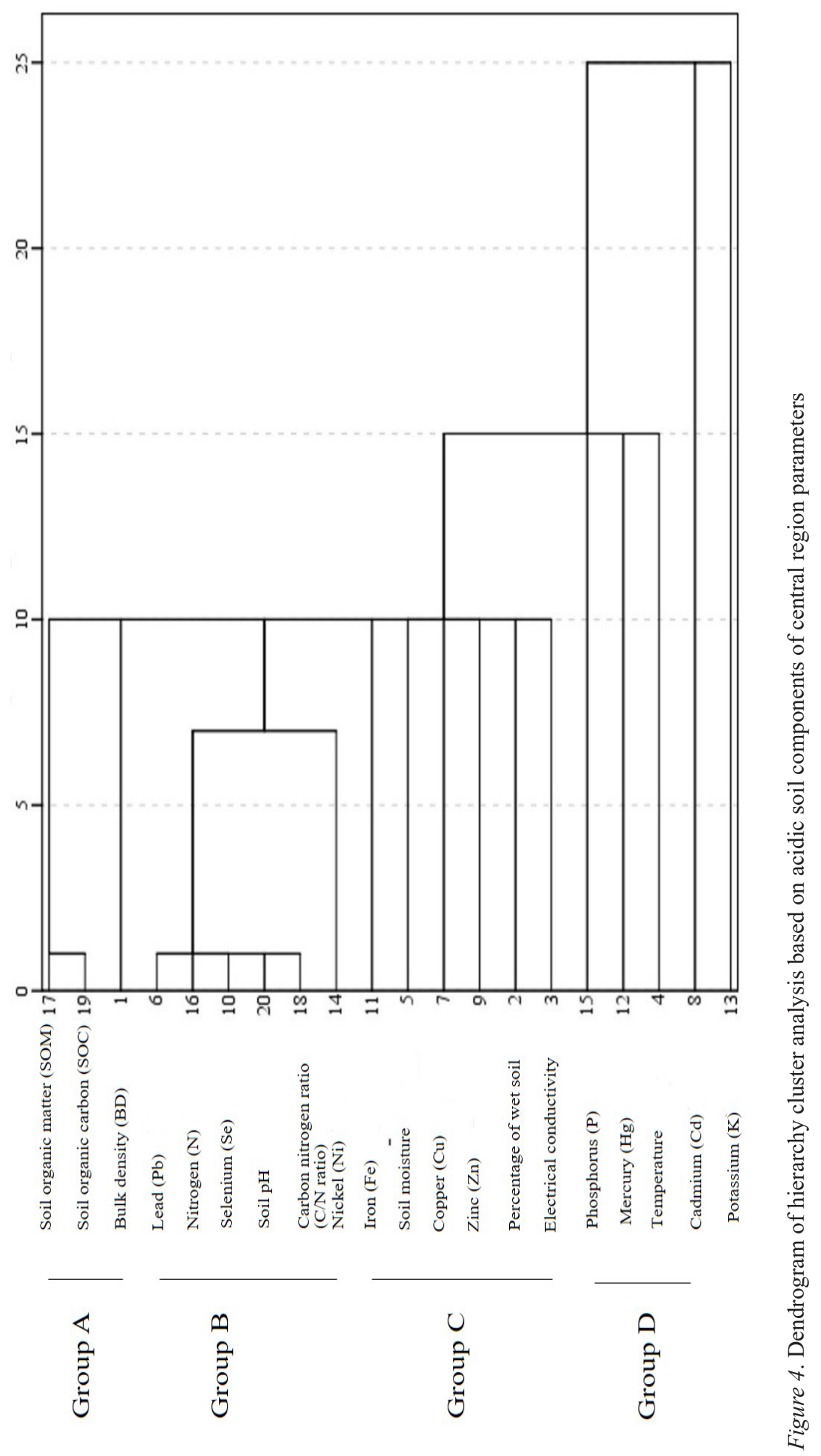

Pertanika J. Trop. Agric. Sci. 44 (3): 541 - 563 (2021) 
microorganism activity in the soil (Neina, 2019). Components of soil $\mathrm{pH}, \mathrm{SOM}$, $\mathrm{SOC}$, and $\mathrm{C} / \mathrm{N}$ ratio are related to iron in the earth due to ferrous disulfide $\left(\mathrm{FeS}_{2}\right)$. In a test to determine the influence of soil $\mathrm{pH}$ on components related to $\mathrm{C} / \mathrm{N}$ ratio $>$ $\mathrm{N}>\mathrm{Ni}>\mathrm{Pb}>\mathrm{Zi}$, it was found that the acidic soil contained large amounts of $\mathrm{Fe}$ and Al oxides (Kamprath \& Smyth, 2005). Kawaguchi and Kyuma (1974) reported that $\mathrm{Fe}, \mathrm{Mn}$, and $\mathrm{Si}$ in the central region were higher than in other parts of the country. Results of a similar study showed that the quantity of Fe was higher than that of other elements (Table 3 ). However, the correlation between the $\mathrm{pH}$ of acidic soil and $\mathrm{Pb}, \mathrm{Zn}$, and Ni may be due to the parent materials of the soil (Anderson, 1988; B. Liao et al., 2005; Brogowski et al., 2014; Nair \& Cottenie, 1971). The soil's parent material in Thailand's central region is non-calcareous sediment, sulfur derived from pyrite, and clay, whose components are kaolinite, muscovite/illite, and smectite (Office of Soil Survey and Land Use Planning, 2010; Spaargaren et al., 1981).

The $\mathrm{pH}$ of acidic soil often varies depending on soil level (Arunrat et al., 2017; Kavinchan et al., 2015; Oechaiyaphum et al., 2020; Perie \& Ouimet, 2007) and is related to the $\mathrm{C} / \mathrm{N}$ ratio. Similarly, Tonon et al. (2010) explained that soil $\mathrm{pH}$ could influence the transformation of organic matter in the soil. However, SOM and SOC are grouped with BD in the dendrogram (Figure 4). Furthermore, it is connected to the result of factor analysis (Figure 3), meaning that there is a positive relationship between SOM, SOC, and BD $(p<0.05)$.

\section{Factors of Soil Organic Matter and Soil Organic Carbon in Some Components of Acidic Soil}

The study shows SOM and SOC in directly related to $\mathrm{BD}$ in the dendrogram (Figure 4) of cluster analysis. PCA and component loading of SOM, SOC, and BD are significant components of PC2 (Figure 3). Therefore, generally, SOM must relate to SOC because it uses a percentage of carbon in its calculation (Han et al., 2018; Y. Liao et al., 2015). However, the relationship between SOM, SOC, and BD is closely related to the organic and inorganic materials in the soil content (Perie \& Ouimet, 2007) and soil type (Athira et al., 2019; Sakin, 2012). Therefore, SOM is important in understanding the behaviour of microbial activity in soil (Gmach et al., 2019; Grand \& Luvkulich, 2012) because it is related to SOC and total nitrogen in the ecology zone. Nevertheless, Sun et al. (2017) reported that capillary water, SOC, and nitrogen have positive interactions with the $\mathrm{C} / \mathrm{N}$ ratio, and the $\mathrm{C} / \mathrm{N}$ ratio will decrease with an increase in soil $\mathrm{pH}$. Therefore, the $\mathrm{C} / \mathrm{N}$ ratio can explain certain minerals in the area (Hamilton et al., 2003; Yang et al., 2019).

\section{Soil Fertility in Acidic Zones of Central Thailand}

This study focused on $\mathrm{N}, \mathrm{P}, \mathrm{K}, \mathrm{Fe}, \mathrm{Cu}, \mathrm{Zn}$, and $\mathrm{Ni}$. The quantity of $\mathrm{Fe}$ and $\mathrm{Cu}$ is high in acidic soil (von Uexküll, 1986). Gazey and 
Davies (2009) explained that $\mathrm{pH}$ is inversely related to nutrient availability of $\mathrm{Fe}, \mathrm{Cu}$, and $\mathrm{Zn}$. Conversely, $\mathrm{N}$ and $\mathrm{K}$ increase with $\mathrm{pH}$, and $\mathrm{P}$ is optimised at a $\mathrm{pH}$ of 6.5. At the study site, however, the number of essential macro and microelements was high compared with the ideal soil for plants
(Table 11). Abundant soil is a valuable element for plants. This study analysed and found a high quantity of $\mathrm{N}, \mathrm{K}, \mathrm{Fe}, \mathrm{Cu}, \mathrm{Zn}$, and $\mathrm{Ni}$ in crude soil samples. The level of $\mathrm{P}$ availability in plants was determined using the Bray II method.

Table 11

Soil element quantity compared with ideal (abundant) soil for plants

\begin{tabular}{lccccc}
\hline $\begin{array}{l}\text { Elements } \\
(\mathrm{mg} / \mathrm{kg})\end{array}$ & Study site & $\begin{array}{c}\text { Shehata and } \\
\text { El-Ramady } \\
(2012)\end{array}$ & $\begin{array}{c}\text { Brunetti } \\
(1950)\end{array}$ & FAO & $\begin{array}{c}\text { Mahler } \\
(2004)\end{array}$ \\
\hline $\mathrm{Fe}$ & 29,765 & 53,600 & $50-100$ & $50,000^{\mathrm{B}}$ & $50-10,000$ \\
$\mathrm{Cu}$ & 40.5 & 60 & $2-5$ & $70^{\mathrm{B}}$ & $2-20$ \\
$\mathrm{Zn}$ & 13.3 & 70 & $6-12$ & $80^{\mathrm{B}}$ & $10-100$ \\
$\mathrm{Ni}$ & 0.19 & 84 & - & $100^{\mathrm{B}}$ & - \\
$\mathrm{N}$ & 782 & $100-200$ & $30,000-$ & $30,000-$ & $10,000-$ \\
& & & 50,000 & $34,000^{\mathrm{A}}$ & 50,000 \\
$\mathrm{P}$ & 131 & $30-50$ & $30,000-$ & $1,100-$ & $1,000-5,000$ \\
& & & 50,000 & $1,200^{\mathrm{A}}$ & $5,000-$ \\
$\mathrm{K}$ & 61.3 & $10-200$ & $40,000-$ & $1,800-$ & 50,000 \\
\hline
\end{tabular}

Note. A represents information in Food and Agriculture Organization of the United Nations (FAO) (1980), and $\mathrm{B}$ represents information in FAO (1979); $\mathrm{Fe}=\mathrm{Iron} ; \mathrm{Cu}=$ Copper; $\mathrm{Zn}=$ Zinc; $\mathrm{Ni}=\mathrm{Nickel}$; $\mathrm{N}=$ Nitrogen; $\mathrm{P}=$ Phosphorus $; \mathrm{K}=$ Potassium

\section{Heavy Metal Contamination in Acidic Soil in Central Thailand}

The soil collected in the agricultural area was tested for heavy metals $\mathrm{Pb}, \mathrm{Cd}, \mathrm{Hg}$, and Se. The contamination level did not exceed the standards set by the Pollution Control Department (2004) for soil in habitat and agricultural areas. The level of $\mathrm{Pb}$ did not exceed any of the limits shown in Table 12, but $\mathrm{Cd}$ and $\mathrm{Hg}$ surpassed the limit according to reports by Crommentuijn et al. (1997) and the FAO (2005), and Se exceeded the limit set by Crommentuijn et al. (1997). However, $\mathrm{Pb}$ has a negative correlation to soil $\mathrm{pH}$ ( $r=$ $-.503 ; p<0.05)$, so it may stimulate fungi activity in acidic soil (Lenart \& WolnyKoladka, 2013). B. Liao et al. (2005) discovered that the relationship between a high level of $\mathrm{Cd}$ and its correlation with soil $\mathrm{pH}$ is related to soil EC. 
Patarapong Kroeksakul, Arin Ngamniyom, Kun Silprasit, Sakawjai Tepamongkol, Punnada Teerapanaprinya and Kewaraporn Saichanda

Table 12

Limits of heavy metal contamination in soil

\begin{tabular}{cccccc}
\hline $\begin{array}{c}\text { Elements } \\
(\mathrm{mg} / \mathrm{kg})\end{array}$ & Study site & Thailand $^{1}$ & $\begin{array}{c}\text { Raymond and } \\
\text { Felix (2011) }\end{array}$ & $\begin{array}{c}\text { Crommentuijn } \\
\text { et al. (1997) }\end{array}$ & $\begin{array}{c}\text { FAO } \\
(2005)\end{array}$ \\
\hline $\mathrm{Pb}$ & 130 & 400 & 600 & 140 & 200 \\
$\mathrm{Cd}$ & 2.25 & 37 & 100 & 1.6 & 1 \\
$\mathrm{Hg}$ & 5.43 & 23 & 270 & 2.2 & 2 \\
$\mathrm{Se}$ & 1.83 & 390 & $\mathrm{ND}$ & 0.81 & 20 \\
\hline
\end{tabular}

Note. ${ }^{1}$ Pollution Control Department standard for soil quality in habitat and agricultural areas; $\mathrm{Pb}=\mathrm{Lead}$; $\mathrm{Cd}=$ Cadmium; $\mathrm{Hg}=$ Mercury; $\mathrm{Se}=$ Selenium; $N D=$ No data

\section{CONCLUSION}

The evaluation of soil acidity in central Thailand found an average $\mathrm{pH}$ of 4.71 \pm 0.87 . The soil acidity level can be categorised as very strongly acidic in Phatum Thani and Nakhon Nayok and strongly acidic in Chachoengsao. Soil $\mathrm{pH}$ and $\mathrm{BD}$ are about $0.34 \mathrm{~g} / \mathrm{cm}^{3}$ in the soil $\mathrm{pH}$ relationship to \% Wet and EC. The \% Wet is related to $\mathrm{BD}$ and $\mathrm{SOC}$ and SOM value because it is linked to microorganisms in soil surface decomposition activity. However, the dendrogram of hierarchical cluster analysis shows that $\mathrm{Se}, \mathrm{Ni}$, and $\mathrm{N}$ have similar pH clusters; it also shows that $\mathrm{Fe}$ is a majors mineral in soil acidity in central Thailand. The correlation of soil $\mathrm{pH}$ to $\mathrm{Pb}, \mathrm{Ni}, \mathrm{N}, \mathrm{C} / \mathrm{N}$ ratio, and $\mathrm{Zn}$ is as follows: $\mathrm{PC} 1$ is $\mathrm{C} / \mathrm{N}$ ratio $>\mathrm{pH}>\mathrm{Zn}$, and $\mathrm{PC} 2$ is SOC $>$ BD $>$ SOM. Soil pH, SOM, and SOC are similar groups, and soil abundance at the study site contained essential macro and microelements below the ideal level needed for plants. The heavy metal contamination of the acidic soil in the central region did not exceed the standard limit. However, the correlation between SOM and SOC ( $r$ $=0.715 ; p<0.01)$ indicates soil quality and microbial activity.

The acidic soil area in central Thailand is a significant zone for agricultural production in the country. The study found a relationship between the element content and soil physical properties. However, the connection is not strong enough to offer suggestions to farmers who have improved their soil over time because the study found many factors related to soil acidities, such as microorganisms in the area or the chemical behaviour of soil acidity in the country. These factors impact farmers improving the soil by stabilisers such as lime, calcite, and dolomite for adjusting $\mathrm{pH}$ in the soil. Therefore, this topic should find practical support in the future, as the search for a solution to soil acidity continues.

\section{ACKNOWLEDGEMENTS}

This research was supported by a generous scholarship from Srinakharinwirot 
University (Cord: 643/2563). In addition, we thank the Faculty of Environmental Culture and Ecotourism for providing instruments for analysis. Finally, we offer sincere thanks to the farmers in Phathum Thani, Nahon Nayok, and Chachoengsao provinces for their support of this soil sample research.

\section{REFERENCES}

Amenyan, O. (1988). The soil factor in crop production: An exploratory study in a humid tropical environment. Agricultural System, 26(1), 51-64. https://doi.org/10.1016/0308$521 \mathrm{X}(88) 90005-4$

Anderson, D. W. (1988). The effect of parent material and soil development on nutrient cycling in temperate ecosystems. Biogeochemistry, 5(1), 71-97. https://doi.org/10.1007/BF02180318

Arunrat, N., Nathsuda, P., \& Ryusuke, H. (2017). Practices sustaining soil organic matter and rice yield in a tropical monsoon region. Soil Science and Plant Nutrition, 63(3), 274-287. https://doi. org/10.1080/00380768.2017.1323546

Athira, M., Jagadeeswaran, R., \& Kumaraperumal, R. (2019). Influence of soil organic matter on bulk density in Coimbatore soils. International Journal of Chemical Studies, 7(3), 3520-3523.

Attanandana, T. (1993). Deficiencies and toxicities of some nutrient elements in acid sulfate soil of Thailand. Agriculture and Natural Resources, 27(4), 508-515.

Bautista, F., Eduardo, G., \& Angeles, G. (2016). The App SOC plus a tool to estimate and calculate organic carbon in the soil profile. Journal of Applied Research and Technology, 14(2), 135139. https://doi.org/10.1016/j.jart.2016.03.002

Brogowski, Z., Wojciech, K., \& Retana, M. (2014). Calculating particle density, bulk density, and total porosity of soil based on its texture. Soil
Science Annual, 65(4), 139-149. https://doi. org/10.1515/ssa-2015-0007

Brunetti, J. (1950). The farm as ecosystem; Tapping nature's reservoir-biology, geology, diversity. Cataloging-in-Publication.

Chien, H. H., Tokuda, M., Minh, V. D., Kang, Y., Iwasaki, K., \& Tanaka, S. (2019). Soil physicochemical properties in a high-quality tea production area of Thai Nguyen province in northern region, Vietnam. Soil Science and Plant Nutrition, 65(1), 73-81. https://doi.org/10.1080/ 00380768.2018 .1539310

Conyers, K. M., Uren, C. N., \& Helyar, R. K. (1995). Causes of changes in $\mathrm{pH}$ in acidic mineral soils. Soil Biology and Biochemistry, 27(11), 1383-1392. https://doi.org/10.1016/00380717(95)00083-Q

Crommentuijn, T., Polder, M. D., \& Van de Plascche, E. J. (1997). Maximum permissible concentrations and negligible concentration for metals, taking background concentrations into account: Report (No. 601501001). National Institute of Public Health and the Environment Bilthoven.

Fontes, F. P. M., \& Alleoni, F. R. L. (2006). Electrochemical attributes and availability of nutrients, toxic elements, and heavy metals in tropical soils. Scientia Agricola, 63(6), 589-608. https://doi.org/10.1590/S010390162006000600014

Food and Agriculture Organization of the United Nations. (1979). Trace elements in soils and agriculture._http://www.fao.org/publications/ card/en/c/6ed 95 f9e-9f79-5add-aa 82 $77 \mathrm{dfd} 864 \mathrm{a} 30 \mathrm{a} /$

Food and Agriculture Organization of the United Nations. (1980). Soil and plant testing as a basis of fertilizer recommendation. http://www.fao. org/3/ar118e/ar118e.pdf

Food and Agriculture Organization of the United Nations. (2005). Environmental management 
Patarapong Kroeksakul, Arin Ngamniyom, Kun Silprasit, Sakawjai Tepamongkol,

Punnada Teerapanaprinya and Kewaraporn Saichanda

(soil quality standards) regulations, 2007. http:// www.fao.org/faolex/results/details/en/c/LEXFAOC151538/

Freedman, B. (1995). Acidification. In B. Freedman (Ed.), Environmental ecology: The ecological effects of pollution, disturbance, and other stresses (pp. 94-143). Academic Press. https:// doi.org/10.1016/B978-0-08-050577-0.50009-1

Gazey, C., \& Davies, S. (2009). Soil acidity: A guide for WA farmers and consultants. The Department of Agriculture and Food.

Gmach, R. M., Mauricio, R. C., Klaus, K., \& Carlos, E. P. C. (2019). Processes that influence dissolved organic matter in the soil: A review. Scientia Agricola, 77(3), 20180164. https://doi. org/10.1590/1678-992x-2018-0164

Grand, S., \& Luvkulich, M. L. (2012). Effects of forest harvest on soil carbon and related variables in Canadian Spodosols. Soil Science Society of America Journal, 76(5), 1816-1827. http://doi. org/10.2136/sssaj2012.0103

Haling, E. R., Simpson, J. R., Culvenor, A. R., Lambers, H., \& Richardson, E. A. (2011). Effect of soil acidity, soil strength and macropores on root growth and morphology of perennial grass species differing in acid-soil resistance. Plant, Cell and Environment, 34(3), 444-456. https:// doi.org/10.1111/j.1365-3040.2010.02254.x

Hamilton, A. C. Jr., Muraoka, T., \& Lavorante, A. F. (2003). Relationship between acidity and chemical properties of Brazilian soil. Scientia Agricola, 60(2), 337-343. https://doi. org/10.1590/S0103-90162003000200019

Han, X., Xu, C., Dungait, J.A.J., Bol, R., Wang, X., Wu, W., \& Meng, F. (2018). Straw incorporation increases crop yield and soil organic carbon sequestration but varies under different natural conditions and farming practices in China: A system analysis. Biogeosciences, 15(7), 19331946. https://doi.org/10.5194/bg-15-1933-2018
Ho, Y. S., Wasli, M. E., \& Permumal, P. (2019). Evaluation of physicochemical properties of sandy-textured soils under smallholder agricultural land use practices in Sarawak, East Malaysia. Applied and Environmental Soil Science, 2019, 7685451. https://doi. org/10.1155/2019/7685451

Intorpetch, B., Wisawapipat, W., Arunlertaree, P., \& Teartisup, P. (2014). Soil physicochemical status and nutrient management for paddy soils in the lower central plain of Thailand after the flood disaster in 2011. Environment and Natural Resources Journal, 12(1), 57-67.

Joris, W. A. H., Caires, F. E., Bini, R. A., Scharr, A. D., $\&$ Haliski, A. (2013). Effects of soil acidity and water stress on corn and soybean performance under a no-till system. Plant Soil, 365(1-2), 409424. https://doi.org/10.1007/s11104-012-1413-2

Kamprath, J. E., \& Smyth, J. T. (2005). Liming. In H. Daniel, (Ed.), Encyclopedia of soils in the environment (pp. 350-358). Elsevier Ltd. https:// doi.org/10.1016/B0-12-348530-4/00225-3

Kavinchan, N., Prasit, W., Stephen, E., Sutthathorn, C., \& Jitti, P. (2015). Soil organic carbon stock in restored and natural forests in northern Thailand. KKU Research Journal, 20(3), 294-304. http:// doi.org/10.14456/kkurj.2015.24

Kawaguchi, K., \& Kyuma, K. (1974). Paddy soil in tropical Asia Part 2. Description of material characteristics. Southeast Asian Studies, 12(2), 117-192.

Lataysh, N., \& Gordon, J. (2004). Investigation of differences between field and laboratory $\mathrm{pH}$ measurements of atmospheric deposition program/national trend network precipitation sample. Water, Air, and Soil Pollution, 154(1), 249-270. https://doi.org/10.1023/ B:WATE.0000022971.59349.fc

Lenart, A., \& Wolny-Koladka, K. (2013). The effect of heavy metal concentration and soil $\mathrm{pH}$ on abundance of selected microbial group within 
ArcelorMittal Poland steelworks in Cracow. Bulletin of Environmental Contamination and Toxicology, 90(1), 85-90. https://doi. org/10.1007/s00128-012-0869-3

Lesturgez, G., Poss, R., Noble, A., Grunberger, O., Chintachao, W., \& Tessier, D. (2006). Soil acidification without $\mathrm{pH}$ drop under intensive cropping systems in Northeast Thailand. Agriculture, Ecosystems and Environment, 4(1-4), 239-248. https://doi.org/10.1016/j. agee.2005.10.020

Liao, B., Guo, O. Probst, A., \& Probst, J. L. (2005). Soil heavy metal contamination and acid deposition: experimental approach on two forest soils in Hunan, Southern China. Geoderma, 127(1-2), 91-103. https://doi.org/10.1016/j. geoderma.2004.11.019

Liao, Y., Wu, W.L., Meng, F.Q., Smith, P., \& Lal, R. (2015). Increase in soil organic carbon by agricultural intensification in northern China. Biogeosciences, 12(5), 1403-1413. https://oi. org/10.5194/bg-12-1403-2015

Mahler, L. R. (2004). Nutrients plants require for growth. https://www.extension.uidaho.edu/ publishing/pdf/CIS/CIS1124.pdf

McKean, K. P. C., \& Brent, W. H. (1989). pH determination and measurement. Ministry of Environment.

Nair, P. K., \& Cottenie, A. (1971). Parent material-soil relationship in trace elements - A quantitative estimation. Geoderma, 2(2), 81-84. https://doi. org/10.1016/0016-7061(71)90014-0

Natural Resources Conservation Service. (1994). SSM - Chapter 3: Examination and description of soil profiles. www.nrcs.usda.gov/wps/portal/ nrcs/detail/soils/ref/?cid=nrcs142p2_054253

Neal, C., \& Thomas, A. G. (1985). Field and laboratory measurement of $\mathrm{pH}$ in low-conductivity natural waters. Journal of Hydrology, 79(3-4), 319-322. https://doi.org/10.1016/0022-1694(85)90062-9
Neina, D. (2019). The role of soil pH in plant nutrition and soil remediation. Applied and Environmental Soil Science, 2019, 5794869. https://doi.org/10.1155/2019/5794869

Oechaiyaphum, K., Hayat, U., Rajendra, P. S., \& Avishek, D. (2020). Impact of long-term agricultural management practices on soil organic carbon and soil fertility of paddy fields in Northeastern Thailand. Geoderma Regional, 22, e00307. https://doi.org/10.1016/j.geodrs.2020. e00307

Office of Soil Survey and Land Use Planning. (2010). Soil data. http://os1101.1dd.go.th/survey_1/ DATA_gr1.htm

Parikh, S. J., \& James, B. R. (2012). Soil: The foundation of agriculture. Nature Education Knowledge, 3(10), 2.

Parkpian P., Pongsakul P., \& Sangtong, P. (1991). Characteristics of acid soils in Thailand: A review. In R. J. Wright, V. C. Baligar, \& R. P. Murrmann (Eds.), Plant-soil interactions at low pH (pp. 397-405). Springer. https://doi. org/10.1007/978-94-011-3438-5_44

Perie, C., \& Ouimet, R. (2007). Organic carbon, organic matter and bulk density relationships in boreal forest soils. Canadian Journal of Soil Science, 88(3), 315-325. https://doi.org/10.4141/ CJSS06008

Pollution Control Department. (2004). Soil quality. http://pcd.go.th/info_serv/reg_std_soil01.html

Prawach, C., Wipanan, I., \& Sureeporn, M. (2017). A quality improvement of manufacturing process for jasmine rice 105 by applying the design of experiment. International Journal of Agricultural Technology, 13(7.2), 2019-2030.

Raymond, A. W., \& Felix, E. O. (2011). Heavy metals in contaminated soils: A review of sources, chemistry, risks and best available strategies for remediation. International 
Patarapong Kroeksakul, Arin Ngamniyom, Kun Silprasit, Sakawjai Tepamongkol,

Punnada Teerapanaprinya and Kewaraporn Saichanda

Scholarly Research Network, 21, 402647. http:// doi:10.5402/2011/402647

Research and Development for Land Management Division. (2006). Soil acidic mapping of Thailand. http://www.ldd.go.th/Lddwebsite/ web_ord/Technical/Map_acidity/HTML/ Acidity_map.html

Sakin, E. (2012). Organic carbon organic matter and bulk density relationships in arid-semi arid soils in Southeast Anatolia region. African Journal of Biotechnology, 11(6), 1373-1377. https://doi. org/10.5897/AJB11.2297

Seeboonruang, U., \& Ichikawa, T. (2007). The effect of acid sulphuric soil restraint by groundwater control in Nakhon-Nayok Province, Thailand. Soils and Foundations, 47(6), 1089-1099. https:// doi.org/10.3208/sandf.47.1089

Shaver, B. R. (1993). Field vs. Lab alkalinity and $\mathrm{pH}$ : Effects on ion balance and calcite saturation index. Groundwater Monitoring and Remediation, 13(2), 104-112. https://oi. org/10.1111/j.1745-6592.1993.tb00441.x

Shehata, S. A., \& El-Ramady, H. (2012). Micronutrients: Uptake and its roles in plants. Print house Fares Abd El-Hameed for Printing and Publishing.

Soil Lecture Team. (2006). Laboratory manual for soil science. Kasetsart University. Kasetsart University Press

Soti, G. P., Jayachandran, K., Koptur, S., \& Volin, C. J. (2015). Effect of soil $\mathrm{pH}$ on growth, nutrient uptake, and mycorrhizal colonization in exotic invasive Lygodium microphyllum. Plant Ecology, 216(7), 989-998. https://doi.org/10.1007/s11258015-0484-6

Spaargaren, C. O., Creutzberg, D., Van Reeuwijk, P. L., \& Van Diepen, A. C. (1981). Thionic fluvisol (Sulfic Tropaquept) central plain region, Thailand; Soil monolith paper 1. International Soil Museum.
Sparks, S. D. (2003). The chemistry of soil acidity. In S. D. Sparks (Ed.), Environmental soil chemistry (pp. 267-283). Academic Press.

Sumner M. E., Fey M. V., \& Noble A. D. (1991). Nutrient status and toxicity problems in acid soils. In B. Ulrich \& M. E. Sumner (Eds.), Soil acidity (pp.149-182). Springer. https://doi. org/10.1007/978-3-642-74442-6_7

Sun, G., Li, W., Zhu, C., \& Chen, Y. (2017). Spatial variability of soil carbon to nitrogen ratio and its driving factors in Ili River valley, Xinjiang, Northwest China. Chinese Geographical Science, 27(4), 529-538. https://doi.org/10.1007/ s11769-017-0885-7

Thummahitsakul, S., Subsinsungnern, R., Treerassapanich, N., Kunsanprasit, N., Puttirat, L., Kroeksakul, P., \& Silprasit, K. (2018). Pesticide and heavy metal contamination: Potential health risks of some vegetables and fruits from a local market and family farm in Ongkharak District of Nakhon Nayok Province, Thailand. Pertanika Journal of Tropical Agricultural Science, 41(3), 987-1001.

Tonon, G. Sohi, S., Francioso, O., Ferrari, E., Montecchio, D., Gioacchini, P., Ciavatta, C., Panzacchi, P., \& Powlson, D. (2010). Effect of soil $\mathrm{pH}$ on the chemical composition of organic matter in physically separated soil fractions in two broadleaf woodland sites at Rothamsted, UK. European Journal of Soil Science, 61(1), 970-979. https://doi.org/10.1111/ j.1365-2389.2010.01310.x

United States Environmental Protection Agency. (1996). Method 3050B: Acid digestion of sediments, sludges, and soils. https://www.epa. gov/sites/production/files/2015-06/documents/ epa-3050b.pdf

Van Ranst, E., Nachtergaele, O. F., \& Verdoodt, A. (2004). Evolution and availability of geographic soil databases. In H. Eswaran, P. Vijarnsorn, T. Vearasilp, \& E. Padmanabhan (Eds.), Innovative 
techniques in soil survey: Developing the foundation for new generation of soil resource inventories and their utilization (pp. 223-236). Land Development Department.

von Uexküll, R. H. (1986). Efficient fertilizer use and acid upland soils of the humid tropics. Fertilizer and Plant Nutrition Service FAO Land and Water Development Division.

von Uexküll, R. H., \& Mutert, E. (1995). Global extent, development and economic impact of acid soils. Plant and Soil, 171(1), 1-15. https:// doi.org/10.1007/BF00009558
Yang, H., Peng, Z., Tongbin, Z., Qiang, L., \& Jianhua, C. (2019). The characteristics of soil $\mathrm{C}, \mathrm{N}$, and $\mathrm{P}$ stoichiometric ratios as affected by geological background in a karst graben area, Southwest China. Forests, 10(7), 601. https:// doi.org/10.3390/f10070601

Zhang, Y., Wang, J., Dai, S., Zhao, J., Huang, X., Sun, Y., Chin, J., Cai, Z., \& Zhang, J. (2019). The effect of $\mathrm{C}: \mathrm{N}$ ratio on heterotrophic nitrification in acidic soils. Soil Biology and Biochemistry, 137, 107562. https://doi.org/10.1016/j. soilbio.2019.107562 
